\title{
The Case for Integrative Sustainable Development Practice Based on the Minas Conga Gold-Mining Experience in Peru
}

\section{Timothy J. Downs*, Andrea Cabrera Roa, Katherine Chyna Dixon, Phyllis Duff, Eric Pasay, Hannah Silverfine}

International Development, Community and Environment Department (IDCE), Clark University, Worcester, USA

Email: *tdowns@clarku.edu

How to cite this paper: Downs, T. J., Roa, A. C., Dixon, K. C., Duff, P., Pasay, E., \& Silverfine, H. (2020). The Case for Integrative Sustainable Development Practice Based on the Minas Conga Gold-Mining Experience in Peru. Journal of Geoscience and Environment Protection, 8, 17-40. https://doi.org/10.4236/gep.2020.85002

Received: February 9, 2020

Accepted: May 5, 2020

Published: May 8, 2020

Copyright $\odot 2020$ by author(s) and Scientific Research Publishing Inc. This work is licensed under the Creative Commons Attribution International License (CC BY 4.0).

http://creativecommons.org/licenses/by/4.0/

(c) (i) Open Access

\begin{abstract}
Mining projects are among the most impactful development projects, and the most controversial. The Conga Mining Project, proposed by the U.S. based Newmont Mining Corporation, in partnership with Minas Buenaventura, was slated for the Cajamarca region of Peru. Since the Environmental Impact Assessment (EIA) was completed in 2010, controversy has escalated: public protests have precipitated a political crisis for President Humala, with several ministers resigning. The proposed project would have been made located approximately $73 \mathrm{~km}$ northeast of the city of Cajamarca, in the northern Peruvian Andes, in the district of Sorochuco, within an area defined by four major lakes, headwaters of rivers, and wetlands. Despite findings of "no significant impact" by the 2010 EIA, the project is currently postponed indefinitely due to the public backlash, international attention, and questions of integrity surrounding environmental and social concerns. We use the Conga Mining case to interrogate business-as-usual (BAU) design, assessment, planning, implementation and monitoring practices for extractive development in Peru, and suggest alternatives. Our analysis is based on an integrative framework that is empirically based (previously developed by the authors), one with a greater likelihood of improving sustainable development and the equity of positive and negative impacts among stakeholders. Suggestions are tailored to the setting: we pay special attention to the climate-change and socio-political contexts of Peru. We seek to exploit a shifting political landscape that is resisting BAU and countering the systematic disenfranchisement of vulnerable populations by extractive resource industries. These appear to be enabling conditions to promote the adoption of a capacity building, socio-technical enterprise approach to framing and designing sustainable development projects in Peru, with implications beyond.
\end{abstract}




\section{Keywords}

Peru, Mining, Sustainable Development, EIA, Capacity Building

\section{Introduction}

\subsection{Global Context}

The need for new approaches to development practice that blend social and technical innovations has become increasingly urgent since the sustainable development (SD) paradigm first took the global stage in the 1980s and 1990s. Reflecting critically on the first 25 years of SD practice, the United Nations concludes: "[A] new political deal is needed, which provides a clear vision and way forward for the international community, national governments, the private sector, civil society and other stakeholders for advancing the sustainable development agenda in an integrated manner" (UN/DESA, 2016). Indeed, almost all development agencies now call for integrative approaches (e.g. USAID, DFID, UNDP, World Bank, GEF).

Mining projects present some of the greatest challenges for sustainability. Exemplifying this sector's particular challenges, the Minas Conga experience illustrates the need for an alternative approach to business-as-usual (BAU) neoliberal economic development practice in Peru. It provides a compelling case study, and an opportunity to propose a fundamentally different process that reframes SD challenges in terms of strengthening adaptive capacity to respond to existing and projected needs, with corresponding integrative methods.

\subsection{Conundrums and Integrative Responses}

Traditional SD practice struggles to tackle three "conundrums" that undermine progress and pose risks (Downs et al., 2017; Downs \& Mazari-Hiriart, 2017):

- The Socio-Ecological Complexity Conundrum: Socio-ecological systems are intrinsically complex, with multiple components linked together and many strong feedback loops.

- The Varying Temporall Spatial Scales Conundrum: Development projects run on relatively short and fixed time frames, but they do not match natural cycles of change, nor embody sufficient adaptability to the unexpected. Likewise, choosing the appropriate spatial scale for projects poses real challenges, with big implications: strong interdependencies exist between system components at smaller and larger scales.

- The Stakeholder Diversity Conundrum: development projects impinge on diverse participants with differing goals, values, and assets. They may participate in different ways, and they will experience significantly different impacts-positive and negative-from a project.

Integrative thinking is gaining ground as an enterprising new approach to sustainable development and poverty reduction projects. For example, the Glob- 
al Environment Facility states: "To solve the sustainability challenges of cities, we need greater knowledge sharing, integrated approaches, and to start thinking differently" (GEF, 2016). This paper tackles the question: How can Minas Conga experience inform the application of new integrative approaches to development practice?

\section{Background}

\subsection{Minas Conga}

The US $\$ 5$ billion Minas Conga/Conga Mining Project, owned by the U.S. based Newmont Mining Corporation, in partnership with Minas Buenaventura of Peru, was proposed in 2004 for the Cajamarca Region (Figure 1). Newmont, the world's 2nd largest gold miner, stopped development of Minas Conga in 2016

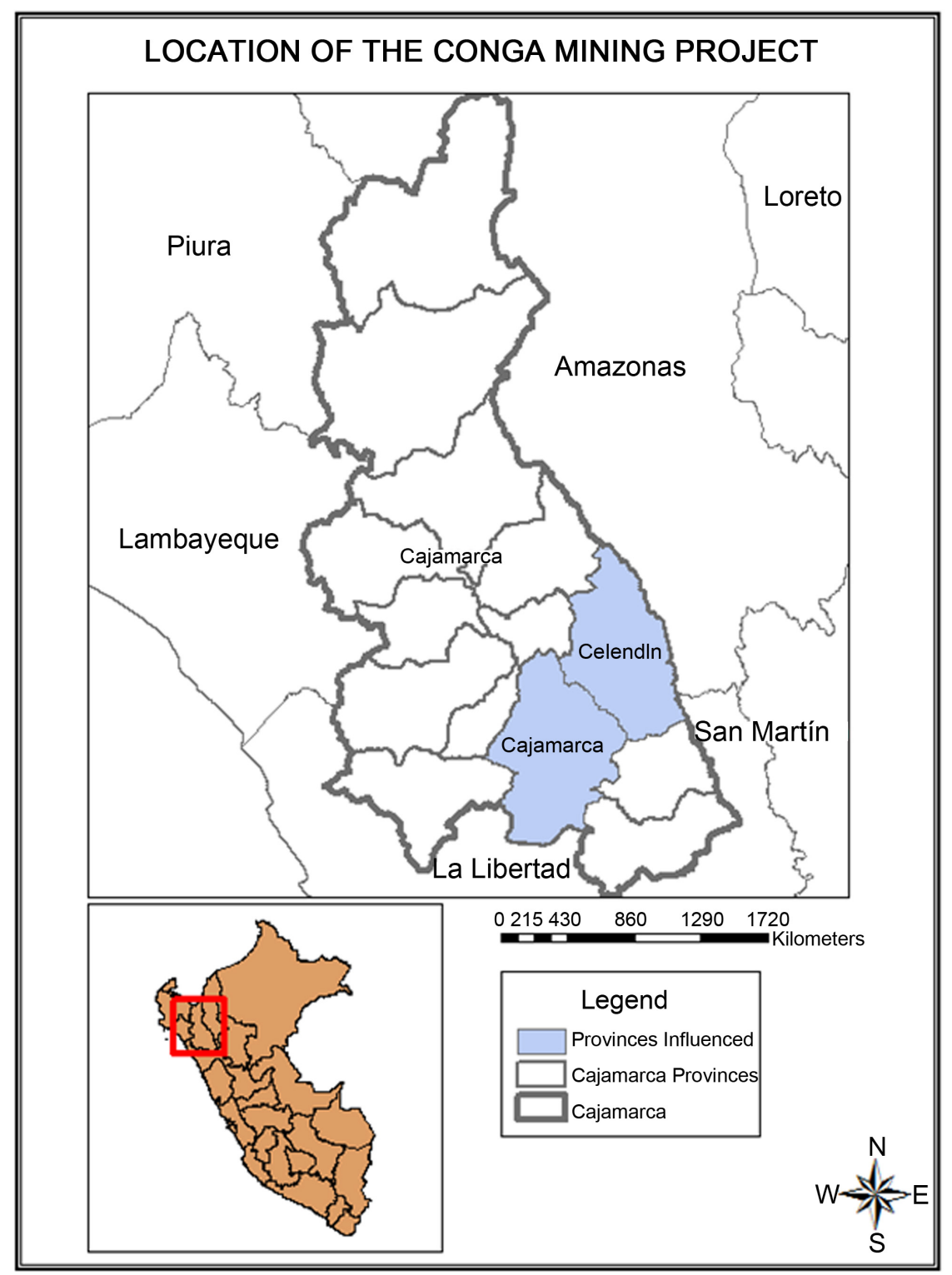

Figure 1. Location of Minas Conga in Cajamarca, Peru. 
after years of public resistance, reclassifying its reserves of gold and copper as resources that it "did not anticipate being able to develop for the foreseeable future" (Jamasmie, 2016). Conga was slated to generate up to 350,000 ounces of gold and 120 million pounds of copper per year for 19 years, and was to be built as an expansion of Newmont's existing Mina Yanacocha, Latin America's largest gold operation. The company first halted Conga development in November 2011, after violent protests led by Cajamarca Governor Gregorio Santos forced the Government of Peru to declare a state of emergency then suspend works. From 2011 to 2016, Minera Yanacocha S.R.L (MYSRL), a conglomerate of Newmont, tried in vain to win local support (ibid).

Sustainability principles are finding their way into the messaging of major companies. Newmont's website says: "Sustainable development is a core part of Newmont's strategy and integrated into every aspect of the business... Our sustainability approach starts with building and maintaining respectful relationships with the communities and governments that host our operations. Mitigating and managing the inherent risks in our business is critical to our success and, more importantly, to our stakeholders' wellbeing. We are committed to the responsible management of resources such as land, air quality, water and biodiversity, as well as putting the health and safety of our people first" (Newmont, 2017).

Minas Conga project site is located approximately $70 \mathrm{~km}$ northeast of the city of Cajamarca, in the northern Peruvian Andes, in the District of Sorochuco, within an area defined by four lakes, river headwaters, and wetlands (Triscritti, 2013). The Environmental Impact Assessment (EIA) of 2010 issued a finding of "no significant impact" (WWF, 2012) and became the lightning rod for public protest. The project was funded in part by the International Finance Corporation (IFC), the private lending arm of the World Bank. Resistance against the project and its impacts represent one of the most potent examples in global development history of civil unrest blocking a development project, making it highly valuable a posteriori.

\subsection{Social, Political, Economic and Ecological Contexts}

Conga site is located in the Cajamarca Region of the Peruvian Andes, comprised primarily of indigenous campesinos. Despite being the majority, "discrimination of the indigenous and mestizo majority by the ruling white elite characterizes Peru's national history" (Javier, 2008: p. 300), Conga exists in an uneasy context of social, economic and political marginalization; despite Newmont's claims that mining invests in the community, "the departments richest in natural resources are among the poorest in the country, with Cajamarca at 64 percent [poverty level]" (Javier, 2008: p. 300). As stated by community organizer Milton Sánchez, "the gold they take out of our region is stained with blood" (Hallman, 2015).

Metals and minerals account for approximately 60\% of Peru's exports. Growth in the mining sector since 2009 has been driven by high global demand 
for gold and silver, bolstered by deregulation to promote mining investment by foreign companies (Bury, 2005). Peru's mining industry is centered in the metals-rich Andes, led by U.S. and Chinese companies (CIA, 2016). Despite considerable tax revenue for the government, little benefit trickles down to civil society. Extreme rural poverty is concentrated in Cajamarca, Piura, La Libertad and Apurimac Regions. Agriculture and livestock are the main sources of income for rural communities in Cajamarca (Hallman \& Olivera, 2015). Environmental degradation from mining is often cited as the primary threat to the livelihoods of rural communities and indigenous Andean peoples (Bebbington et al., 2008; Bebbington \& Williams, 2008), and they gain little if anything in return.

Cajamarca Region lies in the Northern Highlands of Peru, called jalca, the transitional zone between high altitude lakes and drier valleys below. Wet and dry seasons are defined by precipitation and lack thereof (Smith, 1988). The jalca ecosystem comprises over "600 springs, 100 water sources for human consumption, and 18 irrigation canals" (CIEL, 2015). The region is also home to a $5000 \mathrm{~km}^{2}$ watershed, categorized as a major river region (Bebbington \& Williams, 2008). Previous studies have revealed the adverse effects of mining, including deteriorating human, animal and plant health resulting from decreased water quality (ibid). Mining unearths massive amounts of rock and releases previously concealed heavy metals and anthropogenic toxics like mercury and hydrocyanic acid (and cyanide as its secondary pollutant) into the environment. A typical mine also creates a reservoir (on the order of 100s of $\mathrm{Ha}$ in area) "of liquid tailings, and potentially [eliminates/contaminates] the ecosystem services" (CIEL, 2015). Among those services is support for diverse flora and fauna at different altitudes. People in Cajamarca have agrarian livelihoods, being directly impacted by mining-related water pollution, disruptions to water flow, soil erosion and loss of land area (BankTrack, 2012). Indicative of its scale, Minas Conga was slated to impact $62 \%$ of the watershed area directly, with indirect impacts too.

\subsection{Climate-Change Context}

"Peru is South America's most water-stressed country... The Tyndall Centre for Climate Change Research identifies Peru as the world's third most vulnerable country to the impacts of climate change" (Bebbington \& Williams, 2008: p. 191). Under the Intergovernmental Panel on Climate Change (IPCC) emission scenario A2 the Andes could experience a 4 - 5 degree Celsius warming, which would have major impacts on the seasonal hydrological cycle that many people depend on (Vuille \& Francou, 2008). According to the UN (2014), deforestation and receding glaciers in the Andes will impact water resources, and flood and/or drought risks, with subsequent impacts on people, agriculture and infrastructure.

In 2014, Peru hosted the United Nations Framework Convention on Climate Change (UNFCCC) Conference of the Parties 20 (COP20) in Lima. At COP20 it was determined that each country would be responsible for submitting an Intended Nationally Determined Contribution (INDC) prior to the COP21 in Paris 
in 2015 (INDC/Peru, 2015). In what amounts to a sustainable development agenda, Peru's INDC contemplates: decreasing poverty; protecting fisheries; promoting health; investing in public infrastructure; gender equity; disaster risk management; and private sector investment (INDC/Peru, 2015). Thus, projects like Minas Conga run counter to stated national goals, disconnected from a climate-changing Peru.

\section{Methods}

To analyze Minas Conga, we first consider the nature of conundrums in Peru. To tackle conundrums and critique existing practice, we apply an integrative framework of six domains (6-D) (Downs et al., 2017): 1) project framing, concept and design; 2) development topics and sectors; 3) stakeholder interests, relationships and assets; 4) knowledge types, disciplines, models and methods; 5) temporal and spatial scales; and 6) socio-technical capacities and networks. We apply integrative thinking to critique each operational stage of Minas Conga: 1) conceptual; 2) assessment; 3) planning; 4) implementation; and 5) monitoring. For each stage we: a) describe existing practice; and b) suggest improvements.

\section{Findings \& Discussion}

How can Minas Conga experience inform the application of new integrative approaches to development practice?

\subsection{Conundrums}

The socio-ecological complexity conundrum manifests in Peru in the same way it does in many settings: project proponents design and deploy projects in a fragmented manner that ignores this complexity and interdependencies among sectors and issues. Similarly, the temporal and spatial scales conundrum is largely ignored: BAU assessment and planning do not take into account the spatial and temporal dynamics of human livelihoods, ecosystems and hydrological basins that surround the Minas Conga location, and does not treat the landscape as a fabric of interrelated issues. Presidential elections happen every 5 years, so planning tends to be short-term, ignoring the need to consider in parallel, short/urgent-, medium- and long-term planning horizons. Notwithstanding, as evidenced by the strong civil resistance to the project, and its eventual halt, the most serious failing stems from the stakeholder diversity conundrum: the BAU process was classically top-down, driven by the mining corporation, central government and the IFC, reinforcing the chronic marginalization of indigenous groups.

Our constructive response calls for appropriate levels and modes of stakeholder engagement to be considered for each stage of a project, using participatory development methods and tools suited to social, political and cultural contexts (see, for example, Chambers 1995, 1997, 2008), and driven by a socio-technical enterprise philosophy (Downs et al., 2017). Table 1 shows stake- 
holder profiles with respect to Minas Conga: significantly, those opposed represent substantial political and social capital. Given this capital, considering collaborative integrative approaches is timely.

\subsection{Conceptual Stage}

\subsubsection{BAU Conceptual Approach}

The primary objective of Minas Conga was to generate economic revenue for the Peruvian government, and profits for Buenaventura and Newmont. These parties made significant, co-beneficial steps to ensure the "success" of the project, following common practice in Peru (Armstrong et al., 2014). The Humala Administration weakened federal environmental regulations, invested heavily in the mining industry, and supplied armed police during the ensuing social unrest. Buenaventura and Newmont began purchasing land, investing, and lobbying. While Buenaventura/Newmont made attempts to involve the public along the way, key project decisions had already been made, and their efforts were undermined by public mistrust and their poor reputation in the region. BAU behavior by the corporations has included misleading poor, often illiterate, landowners about benefits they will receive, and the creation of an opaque, biased EIA (Moran, 2012; CAO Assessment Report, 2014). Cajamarca landowners, farmers and herders have been impacted most adversely by mining. Land allocation for mining displaced families, threatened cultural and environmental resources, and disrupted livelihoods. At the regional scale, Conga's location threatened water quality for downstream inhabitants and created an opportunity for the Rondas Campesinas to assert their power (Moran, 2012; PIIC, 2013). Instead of increasing the community's ability to meet its cultural, social, economic and basic resource needs-fundamental development project goals-the mine threatened existing ways of life and offered limited opportunities for direct employment. Ultimately, at cessation of operations, none of the major needs of local and regional civil society stakeholders had been met, and mining company shareholders lost their investment, bringing Newmont's viability into question. Failure of this project further questioned the goals of IFC/World Bank to promote "opportunity for all” using top-down policies, after decades of growing controversy over this model.

\subsubsection{Suggested Conceptual Approach}

This is the most important stage to recast practice since it drives all else. An inclusive, transparent approach to development is needed to better meet the needs of all stakeholders. The objective of any proposed mine as a "development project" should be to strengthen local/regional communities economically and socially, and to mitigate ecological harm, while providing reasonable levels of revenue for each tier of government and the involved corporations. The conceptual stage should contemplate alternative proposals, including no mine at all, BAU gold mining, alternative mining techniques and viable non-mining ways to meet development needs that vary in terms of scale and location. One option is for 
Table 1. Stakeholder profiles with respect to Minas Conga. Shading indicates those against Minas Conga/BAU development practice, representing considerable political and social capital.

\begin{tabular}{|c|c|c|c|c|c|}
\hline Type of Actor & & Leader & Scope & Concern(s) & $\begin{array}{l}\text { Position on } \\
\text { Minas Conga }\end{array}$ \\
\hline \multirow{6}{*}{ Governmental } & $\begin{array}{l}\text { Government of } \\
\text { Peru }\end{array}$ & $\begin{array}{l}\text { President } \\
\text { Ollanta } \\
\text { Humala }\end{array}$ & National & $\begin{array}{l}\text { Ensure the } \\
\text { continuity of the } \\
\text { extractive } \\
\text { economic policy } \\
\text { and economic } \\
\text { growth on the } \\
\text { basis of income } \\
\text { redistribution } \\
\text { of mining } \\
\text { resources. }\end{array}$ & \multirow{3}{*}{$\begin{array}{l}\text { Early strong } \\
\text { promoter. } \\
\text { Now unclear } \\
\text { in face of } \\
\text { unrest }\end{array}$} \\
\hline & $\begin{array}{l}\text { Ministry of } \\
\text { Energy and } \\
\text { Mines }\end{array}$ & $\begin{array}{l}\text { Minister of } \\
\text { Energy and } \\
\text { Mines: Rosa } \\
\text { María Ortíz } \\
\text { Ríos }\end{array}$ & National & $\begin{array}{l}\text { Support } \\
\text { economic } \\
\text { investment. }\end{array}$ & \\
\hline & $\begin{array}{l}\text { Ministry of } \\
\text { Environment }\end{array}$ & $\begin{array}{l}\text { Minister of } \\
\text { Environment: } \\
\text { Manuel Pulgar } \\
\text { Vidal }\end{array}$ & National & $\begin{array}{l}\text { Ensure } \\
\text { environmentally } \\
\text { responsible } \\
\text { mining } \\
\text { investments. }\end{array}$ & \\
\hline & $\begin{array}{l}\text { Provincial } \\
\text { Municipality } \\
\text { Cajamarca }\end{array}$ & $\begin{array}{l}\text { Mayor: Manuel } \\
\text { Becerra Vilchez }\end{array}$ & Provincial & $\begin{array}{l}\text { Investment } \\
\text { promotion }\end{array}$ & \\
\hline & $\begin{array}{l}\text { Regional } \\
\text { President of } \\
\text { Cajamarca }\end{array}$ & $\begin{array}{l}\text { Regional } \\
\text { President } \\
\text { Cajamarca: } \\
\text { Gregorio Santos }\end{array}$ & Regional & $\begin{array}{l}\text { Environmental } \\
\text { and social } \\
\text { impacts of } \\
\text { mining. }\end{array}$ & Against \\
\hline & $\begin{array}{l}\text { Provincial } \\
\text { Municipality } \\
\text { Celendín }\end{array}$ & $\begin{array}{l}\text { Jorge Luis } \\
\text { Urquía } \\
\text { Sánchez }\end{array}$ & Provincial & $\begin{array}{l}\text { Environmental } \\
\text { and social } \\
\text { impacts of } \\
\text { mining. }\end{array}$ & Against \\
\hline Private Sector & $\begin{array}{l}\text { Newmont } \\
\text { Mining (U.S.) } \\
\text { Corporation, in } \\
\text { partnership } \\
\text { with Minas } \\
\text { Buenaventura } \\
\text { (Peru). }\end{array}$ & & $\begin{array}{l}\text { National } \\
\text { and } \\
\text { regional }\end{array}$ & $\begin{array}{l}\text { Resource } \\
\text { extraction for } \\
\text { a profitable } \\
\text { business. }\end{array}$ & For \\
\hline Political Parties & $\begin{array}{l}\text { Social } \\
\text { Affirmation } \\
\text { Movement } \\
\text { (MAS) }\end{array}$ & & Regional & $\begin{array}{l}\text { Remain in the } \\
\text { regional } \\
\text { government, } \\
\text { projections as a } \\
\text { political force at } \\
\text { the national level. }\end{array}$ & Against \\
\hline
\end{tabular}




\section{Continued}

\begin{tabular}{|c|c|c|c|c|}
\hline & $\begin{array}{l}\text { Land and } \\
\text { Freedom } \\
\text { Movement }\end{array}$ & National & $\begin{array}{l}\text { Build a national } \\
\text { eco-political } \\
\text { movement } \\
\text { questioning the } \\
\text { extractive } \\
\text { economic model. }\end{array}$ & Against \\
\hline \multirow{2}{*}{ Civil Society } & $\begin{array}{l}\text { Rondas } \\
\text { Campesinas }\end{array}$ & Regional & $\begin{array}{l}\text { Domestic } \\
\text { violence, } \\
\text { criminality, water } \\
\text { scarcity, mining. }\end{array}$ & Against \\
\hline & $\begin{array}{l}\text { Environmental } \\
\text { Defense Front } \\
\text { of Cajamarca }\end{array}$ & Regional & $\begin{array}{l}\text { Water scarcity, } \\
\text { environmental } \\
\text { impacts. }\end{array}$ & Against \\
\hline \multirow[t]{2}{*}{ Social Media } & $\begin{array}{l}\text { "Mi Mina } \\
\text { Corrupta" }\end{array}$ & Provincial & $\begin{array}{l}\text { Broadcast of } \\
\text { technical, legal } \\
\text { and } \\
\text { environmental } \\
\text { information } \\
\text { about extractive } \\
\text { industries. }\end{array}$ & Against \\
\hline & "Red Verde" & Provincial & $\begin{array}{l}\text { Defense of land } \\
\text { rights. }\end{array}$ & Against \\
\hline Others & $\begin{array}{l}\text { Catholic } \\
\text { Church } \\
\text { Cajamarca }\end{array}$ & Regional & $\begin{array}{l}\text { Empowerment } \\
\text { of local } \\
\text { communities. } \\
\text { Protection of } \\
\text { natural resources. }\end{array}$ & Against \\
\hline
\end{tabular}

communities to own a portion of the mine and to be allocated a significant amount of revenue for development. As compensation for adverse impacts, the Peruvian government should commit up-front to investment in public services in the region, such as safe drinking water supply, adequate sanitation, healthcare, education and transportation.

Transparency throughout each stage of the development project is fundamental to enhance participation and make benefits more equitable (Armstrong et al., 2014). It is important that all major stakeholder groups play a meaningful role in the conceptual stage and the articulation and prioritization of legitimate needs to justify the project in the first place. The first practical step is to have regular, open forums with all stakeholders. These meetings must be made public and facilitated by a trusted independent group of professionals or academics (Slocum, 2003). Each stakeholder should have an equal voice, equal time to speak, and access to the same information resources as others. During meetings, the needs and concerns of each stakeholder can be expressed, outlined, listened to respectfully, and incorporated into the dialogue. Information transparency is stressed, particularly to generate trustworthy impact assessments, with any "successful" project comprising impact tradeoffs and reasonable impact equity 
among stakeholders. To protect against corruption and bias, underrepresented communities would be encouraged to use their social networks to increase power. For example, church, school and/or university groups can educate community members and watch for signs of injustice or manipulation, such an increase in land purchases. Outside watchdog groups and NGOs/INGOs can serve an important role in helping to facilitate community engagement and providing resources to empower local leaders.

Our suggested conceptual stage includes the contemplation of planning horizons that work in parallel: a 5-year short-term planning horizon to tackle urgent issues that can be resolved with existing capacity (in-line with political terms); a medium-term planning horizon out to 2030 (in-line with the SDGs); and a long-term one out to 2050. The 2030 and 2050 horizons allow for capacities to be developed to meet projected and emergent needs such that the response to agreed-upon development needs is not constrained by the limits of existing capacity, rather conceived as being grown to meet changing needs and conditions, as an integral part of any ongoing development activity.

\subsection{Assessment Stage}

\subsubsection{BAU Assessment}

The assessment approach used for Minas Conga relied primarily on the results of an expert-driven EIA completed by the consulting firm Knight Piésold and Co. (WWF, 2012), and approved by Peru's Ministry of Energy and Mines (MEM). Strongly suggestive of bias to mining interests, it made a "finding of no significant impact" (FONSI) in the environmental arena, and a net positive socio-economic impact (ibid). Immediately following the MEM approval and publication of the EIA, findings were vigorously challenged by the community. See Appendix that summarizes major findings in the water category (WWF, 2012), with our critique added, and insights from Vela-Almeida et al. (2016). Our critique provides a check on findings: given the socio-ecological complexity conundrum (1.2), we apply a systems view to reveal bias in favor of Conga, and flaws in logic with regard to watershed-scale hydrology.

The pre-existing Mina Yanacocha underwent a similar assessment process, and the legacy of environmental and social degradation resulting from this mine continues to leave its mark. Communities have good reason to believe that the historic issues with Yanacocha resulting from inadequate assessment and implementation will be replicated with Conga: "the long histories of poor corporate environmental practice and of weak state regulation have left communities distrustful of the central government and mining companies" (Bebbington \& Williams, 2008: p. 192). Mistrust is justified: Yanacocha produced water contamination and land tenure conflict, and it lacked environmental protection. For example, until the mid-1990s Yanacocha claimed to be "upholding U.S. EPA environmental standards", for which it was recognized by the Ministry of Energy and Mines as a "leader of environmental quality in the mining sector". However, 
in response to recent allegations of watershed contamination, mine officials have appealed to forgo regulatory compliance with Class III standards (Fish Consumption, Recreation, Propagation and Maintenance of a Healthy, Well-Balanced Population of Fish and Wildlife) (Bury, 2004: p. 86).

The 2010 EIA of Conga uses a dubious "baseline assessment" of the affected region that would tend to obscure new impacts. By using ecological study data obtained between 2003 through 2009 as baseline (WWF, 2012: p. 104)—data that do not precede Mina Yanacocha, rather representing a degraded state caused by its operation-this cannot be considered a pre-mining baseline. Considering of projected adverse impacts on hydrology, the EIA puts forth technical solutions that claim to neutralise them. For example, the EIA notes that in order to successfully complete the mining operation in an "ecologically sound" manner, multiple primary and ancillary facilities will need to be built. These recommended facilities include topsoil stockpiles, pits, concentrator plants, a tailings storage facility, reservoirs, an acid-water treatment plant, road infrastructure and power infrastructure (WWF, 2012). Bebbington \& Williams (2008: p.190) state: "impacts on water quality and quantity are among the most contentious aspects of mining projects.... Companies insist that the use of modern technologies will ensure environmentally friendly mining practices. However, evidence of the negative environmental impacts of past [Yanacocha] mining activity causes local and downstream populations to worry that new mining activities will adversely affect their water supply".

Significantly, the EIA preamble states: "Impact identification is the process through which all potential impacts that would be generated by the project during its different stages and at surrounding communities without a management plan [emphasis added] are explained. This exercise is a core item of the impact analysis. The required information to complete this stage is collected from several sources, such as the project description, characterization of the population settled in the area, and professional specialized opinions on different social and environmental issues based on previous experience" (WWF, 2012: p. 141). Thus, Conga EIA process is fundamentally flawed: only minor impacts that will not be technologically managed come to the fore in the calculus: the most serious impacts are negated by the dubious claim that they can be managed. This runs counter to classic EIA according to the 1969 U.S. National Environmental Policy Act model (Downs, 2008); lacking comprehensive, transparent consideration of positive and negative impacts among development alternatives forestalls sustainable development choices. Furthermore, the EIA included a post-project inception social communication plan to mitigate negative perceptions, one that clearly failed. Lastly, there was no consideration of climate-change scenarios and impacts (see 2.3), and how they may magnify or modify the impacts of mining activities.

\subsubsection{Suggested Assessment}

Assessment needs to be strongly integrative in all the ways articulated by the 6-D 
framework. We suggest stakeholders co-create a shared information/knowledge resource that undergirds all other efforts toward sustainability. At this stage, we ask: What are the existing and projected development needs for Cajamarca and Peru (including under climate scenarios)? What is the existing capacity, and how can it be strengthened over time? What are the baseline conditions and indicators of relevance to the assessment of impacts and tradeoffs-positive and negative-for a BAU mining project compared against a set of viable alternatives (1969 NEPA model)? The indicators used to compare the projected impacts of BAU vs. alternatives should be a subset of the indicators used to monitor and track baseline conditions. Assessment and planning stages need to be closely connected: a diverse set of sustainability indicators needs to be used, determined by way of a deliberative and generative stakeholder engagement process. The indicators become the metrics and modes of assessing baseline conditions, and the criteria for comparing the projected positive and negative impacts of alternative projects. In this way, we draw on, and enhance, conventional EIA to make it an integral part of the sustainable development assessment and planning process (Downs, 2008). Among the criteria list of indicators will be those related to the new Sustainable Development Goals (SDGs) for 2030, but it is important that any set of indicators used for decision making be chosen via vibrant stakeholder engagement. The stakeholder diversity conundrum reveals that sustainable solutions/responses depend on democratizing how needs are defined, how alternatives are chosen, how criteria/indicators are chosen, and how the deliberative process takes place.

Robust EIA depends on the choice of indicators, and they should be identified using a participatory process. Pollution within the watershed, for example, is an obvious key indicator type; however, more nuanced indicators may be chosen in dialogues with stakeholders. A monitoring system such as that suggested by Bebbington \& Williams (2008: p. 192) is highly appropriate for this project. "The monitoring plan should have the capacity to adapt to changes in mine operations as the mine grows, closes old operations, and explores new areas". In general terms, participatory EIA is necessary for a sustainable project. Not only will this engagement ensure a more reliable model for beginning stages, but it will also secure a less volatile path of implementation. Any improved process requires that communities participate in EIA modeling of a mine's projected impact on the environment, particularly hydrology. To capture inequities, we strongly suggest that best practices in participatory GIS be used to model the spatial distribution of positive and negative impacts, as an integral part of participatory EIA.

Participation should be regarded "as an evolutionary process in which activities at the project level can create the conditions for an increased popular participation in [the mine] at the local, regional or national levels" and as "an active process whereby beneficiaries influence the direction and execution of development projects rather than merely receive a share of project benefit" (Bamberger, 1988). To assess existing community capacity, how to strengthen it, and the ap- 
propriateness of partnership, it is recommended that both external and community-based evaluations of community leadership and capacity be undertaken. It is critical to understand whether the voices representing a population are truly representative of diversity (esp. marginalized groups), and mitigate any historic leadership and social structures that adversely affect the integrity of participation (ibid). Existing influencers should be documented-such as agrarian coalitions, religious groups or other influential bodies-alongside a gender and cultural dynamics evaluation. Without careful, gendered attention to the stakeholder diversity conundrum, "the evidence that women will not be able to contribute fully or to receive their full share of the benefits of many kinds of projects unless the projects are specifically designed to take into account the special needs and potentials of women in a particular culture and socioeconomic environment is extensive" (Bamberger, 1988: p. 2).

In the Conga case, an unbiased baseline assessment needs to include two baselines to be effective for EIA: 1) pre-Yanacocha baseline and what impacts have ensued since that mine was built; and 2) an existing-state baseline that contemplates changes projected for Conga to an already impacted landscape (informed by the first baseline). Local knowledge of the environment's natural pre-mining baseline would inform an appropriate pre-Conga baseline for the EIA, accounting for the considerable pre-existing impacts of Mina Yanacocha. For the ecological baseline of the 2010 EIA “...the water data are not chronologically uniform because project research personnel were denied complete access to the relevant water monitoring data by the Peruvian Ministry of Energy and Mines and Yanacocha" (Bury, 2004).

Last but not least, climate change must also be factored in. Projected regional climate stress-in combination with mining stressors-could greatly magnify social, economic, political, and ecological impacts. It is therefore important for any EIA process to take climate change into consideration over the lifetime of mining operations (19 years for Conga), as well as its long-term (30-50-100 year) post-mining ecological footprint.

\subsection{Planning}

\subsubsection{BAU Planning}

To understand the BAU planning process, we look first at Mina Yanacocha-the largest gold mine in South America-and predecessor of Conga; Conga followed the same model. In the early 1990s, President Alberto Fujimori introduced a neoliberal agenda that spurred the privatization of natural resources (water and lands) by transnational corporations, boosting exports and government tax revenues, but undermining public services and goods. Like Conga, the inception of Minas Yanacocha in 1992 was also a partnership between Newmont Mining Corporation, Companía de Minas Buenaventura and the IFC/World Bank. These three entities combined to form Minera Yanacocha S.R.L. (MYSRL). The first step for MYSRL was to obtain land. While planning the transition of land from Peruvian land owners-many of them locals - to a corporation falls under state 
jurisdiction, the "land reform" measures of Fujimori's government left a gap in state oversight (Bury, 2005). MYSRL planned the process of land transfer, and while it did set up community meetings to engage with landowners, the company had complete control over land-titling. Furthermore, in valuing the land, MYSRL paid current estimated market value rather than projected value, angering many community members. Without specific regulations for planning land transitions, a problematic foundation for the implementation of Yanacocha and later Conga was created (Bury, 2004).

The expansion of Yanacocha via Minas Conga seemed to prioritize community engagement in the planning process. The document "A Legitimate Path Forward: Yanacocha's Community Engagement Progress" outlines historical and ongoing efforts by the company to involve the local community in planning. Its stated objectives are: 1) To be respectful of Cajamarca; 2) to be a development partner for Cajamarca; 3) to be a responsible actor in the water and environment arenas; and 4) to be transparent and credible. Specific measures such as their "Leaders of Knowledge" program, their grievances and complaints mechanism, dialogue forums, water supply improvements and more all seem to highlight their "focus on legitimacy". The document further mentions that the expansion project Minas Conga had been suspended indefinitely in 2015-just before 2016 cessation-in order to plan for "improved organization". MYSRL began building reservoirs to improve water supply infrastructure and benefit the community. However, the fatal flaw in the planning process was that in spite of these moves, in practice it was after-the-fact: there had been no mechanism by which civil society was meaningfully able to influence the conceptual, assessment and planning stages of either Yanacocha or Conga. Most influential was lived experience: the community had lived with the adverse impacts of the Yanacocha since 1992, fostering powerful mistrust and resentment of MYSRL and the Peruvian Government.

\subsubsection{Suggested Planning}

The suggested planning approach would involve engagement from all major stakeholder groups, and a vibrant interaction between conceptual, assessment and planning stages such that needs can be interrogated, and alternatives can be compared using a diverse set of impact indicators under modeled scenarios (in-line with robust participatory EIA, Downs, 2008). Civil society is a primary stakeholder in this stage, including landowners and community leaders who have extensive relevant local knowledge.

We further suggest that alternative planning undertake a new framework for valuing impacts. Bury argues for impacts to be considered on produced capital, human capital, natural capital and social capital (Bury, 2004: p. 79). In this way, planning can value the outcomes of a project through more comprehensive and all-encompassing factors, measured with impact indicators that matter to stakeholders, and with appropriate units (Downs, 2008). According to further research within Cajamarca, the success of Newmont/MYSRL in engaging commu- 
nity members in a legitimate way fell far short and greatly underestimated socio-political resistance. Bury explains how previous negative experiences of Mina Yanacocha held sway, “...as Yanacocha has negatively impacted household access to natural and social resources, they have also mobilized and strengthened the political relationships between households and supra-communal organizations that are focused on resisting these changes. These linkages have extended all the way to the transnational level" (Bury, 2004: p. 88).

In addition to involving local community members, part of creating a more cohesive, integrative project would be to better understand the historical context of the land, and the social system in which the mine is being proposed. One model can be found in Canada's newly established "Leap Manifesto" (LEAP, 2015). Written by Canadian stakeholders from a variety of backgrounds such as labor movements and social and environmental justice groups, the manifesto seeks to recognize the violent history of land acquisition and inequality in Canada, and move towards joint stewardship of the future. We suggest that Minas Conga (and any future projects) adopt similar principles from the United Nations Declaration on the Rights of Indigenous Peoples, Article 18: "Indigenous peoples have the right to participate in decision-making in matters which would affect their rights, through representatives chosen by themselves in accordance with their own procedures, as well as to maintain and develop their own indigenous decision-making institutions" (UNDRIP, 2008). A framework for engagement that begins with a historical, justice-orientated acknowledgement would foster trust and enable participatory planning (LEAP, 2015).

\subsection{Implementation}

\subsubsection{BAU Implementation}

Conga is not just another example of top-down BAU development; it is one that inspired resistance that successfully challenged this model. In its wake, it presents an opportunity for an alternative approach where co-production of social, technical and scientific knowledge is central, and principles of inclusion, participation, and transparency are upheld (Meadow et al., 2015). Following recommendations from Downs et al. (2017), Gifford \& Kestler (2008) and Hilson \& Murck (2000), we strongly suggest a process that invests heavily in strengthening socio-technical capacity and re-frames the stakeholder diversity conundrum in terms of assets. Interestingly, Newmont/MYSRL anticipated backlash well before the EIA was published in 2010: in 2005 it commissioned a team of researchers from the Center of Global Health at the University of Colorado Denver (Gifford \& Kestler, 2008). This team traveled to the Conga area and completed multiple interviews related to community health, activities, and policies. Somewhat in line with our suggested social enterprise approach, it identified key stakeholders and laid out recommendations for Newmont in terms of capacity building and developing a local legitimacy strategy. Notwithstanding, although the company took a step in the right direction then, Gifford \& Kestler's (2008) caveat was: “...the implementation of [these] recommendations will depend to a large de- 
gree on the economy, [and] attitudes of future managers at Newmont". It was a step too late: the timing (2008) and language of the legitimacy plan/strategy reads as a way to mitigate and minimize social resistance toward Minas Conga as it is being implemented and after it becomes operational.

\subsubsection{Suggested Implementation}

In line with sustainability principles, from the outset, a mining development's overarching goal should be to be profitable while either maintaining or enhancing the wellbeing of human beings and the environment in which it operates (Hilson \& Murck, 2000). Mining companies, governments, lenders and civil society must enter into authentic, mutually beneficial partnerships that articulate and honor sustainable development goals. Hilson \& Murck (2000) suggest four goals: cleaner technology implementation; improved environmental management; increased stakeholder involvement; and improved training for communities and employees. Continuing this capacity building theme in the context of Conga, Gifford \& Kestler (2008) also suggested: co-invention of community needs and issues; planning and investing in developments that enhance communities; and planning and investing in community infrastructure.

\subsection{Monitoring}

\subsubsection{BAU Monitoring}

Monitoring methods recommended in the 2010 EIA (WWF, 2012) included: air quality measuring stations; noise and volume measuring stations; channel characteristics, flow measurements, and surface water quality surveys for five hydrological basins; as well as groundwater and hydrogeological monitoring stations. To its credit, it also made innovative recommendations on process and outcomes that are in-line with our integrative approach: socio-environmental participatory monitoring; psychosocial monitoring; a social communication plan; local development planning for short, medium, and long-term priorities; economic monitoring during the mine's lifetime (pre-construction, operation, closure); and shared environmental monitoring trainings. The proposed timeline for monitoring the social, environmental, economic, and political impacts of the project extends from 2011-2030. One of the major objectives of the proposed monitoring process includes creating "engagement tools" that develop a "trustful relationship" between the Conga mining title holders, and local and regional leaders. Specific goals of the monitoring process include: strengthening local skills in using monitoring processes; providing prompt and suitable information to stakeholders; and holding community meetings that assess the company's implementation of mitigation measures as stated in the EIA (WWF, 2012). Notably, proposed monitoring was more integrative than other stages, but it is unclear how the detection of any adverse impacts during monitoring would modify operations to mitigate them, suggesting they may be largely tokenistic.

\subsubsection{Suggested Monitoring}

Project impact monitoring and evaluation (M\&E) needs to be an integral part of 
ongoing dynamic baseline monitoring that is linked to pivotal conceptual, assessment and planning stages: there needs to be strong feedbacks between the monitoring of impacts post-implementation and ongoing assessment and planning activities for future projects or changes to existing projects. Modeled impact indicators-e.g. projected water quality, area of land use/cover change from wetland to mining or farmland to mining, regional employment level-used to compare project alternatives during assessment (see 4.2) and planning (4.3) should be a primary focus of ongoing monitoring. Integrative monitoring is tasked with tracking actual, not EIA-modeled, post-project impacts and conditions, to form the core of a comprehensive set of social, cultural, economic, political and ecological assessment indicators. These data should populate the shared information resource that stakeholders co-create, which becomes the center of a socio-technical enterprise/capacity building network (Downs et al., 2017). The use of tools like surveys and reports from the government, academia and third party organizations would be the basis of much of this monitoring, supplemented by data inputs from civil society using the growing cell phone network. To convey this information on the outcomes of any development project to stakeholders, timely online maps and reports should be issued. Community engagement NGOs working with academic researchers/universities play a vital role in this process: designing and coordinating data collection, analysis and interpretation; training stakeholder groups in data collection; gate keeping and QC/QA on datasets; and oversight of $M \& E$ reporting and ongoing activities. In this regard, we see the pivotal role of the academic sector-esp. in-country and international networks of universities-as technical supports to the capacity building enterprise.

Defining appropriate temporal and spatial scales prior to beginning monitoring is essential, as development conundrums and the 6-D framework signal (see 1.2). The temporal scales of the monitoring process should extend for the working lifetime of the mine (it would have been 19 years in the case of Conga), but extend to a longer term after operations have ceased and post-mining activities and restoration begin. Timelines should be based on the goals established for the overall integrative development program itself, and for different parts of the program; each constituent project will have its own implementation timeline, with goals over short- and long-term horizons. The spatial scales chosen for assessment and monitoring will depend on the requirements of the overall integrated development program, and those of its constituent projects: a watershed scale is appropriate for any large-scale mining project like Conga.

\section{Capacity Building Enterprise}

The scaling-up of localized SD success, and the scaling down of regional efforts, is one of the most persistent challenges for SD work, and is central to the varying temporallspatial scales conundrum. How can SD practice operate on a large scale, without losing its capability for responding to particular local circumstances? Using Minas Conga as a potent case study, the suggested integrative SD 
practice (see 1.2, 3.0 and 4.0) can be usefully framed as a socio-technical capacity-building enterprise (Downs et al., 2017); the underpinning domain of the integrative framework is Domain \#6: socio-technical capacities and networks. These in turn comprise six levels: 1) political and financial seed capital; 2) education, training and awareness raising; 3 ) information and knowledge resources; 4) policy making and planning; 5) appropriate technology and infrastructure; and 6) enterprise development, especially the provision of local/regional products and services (Downs, 2001, 2007).

As we have shown in other work on sustainable urbanization (Downs, 2018), we can configure these levels to exploit interdependencies among sectorswater, agriculture, industry (extractive and manufacturing), transportation, energy, health, and so on-such that level 3 information resources becomes the integrating activity which all other levels both contribute to, and are served by. Thus, we collectively build capacities that serve multiple sectors and stakeholders, with economies of scale and benefits that offset transaction costs. Recognizing the primary importance of integrative knowledge is not new: the topic of knowledge systems for SD work has been receiving attention for some time (Cash et al. 2003). What becomes transformational, in theory, is the development of integrative knowledge networks that can operate at the local scale to address local SD needs, then be interconnected via their information cores such that they grow into regional and national networks: the local networks feed the larger ones, and vice versa, creating a distributed, socio-technical capacity building network (Figure 2).

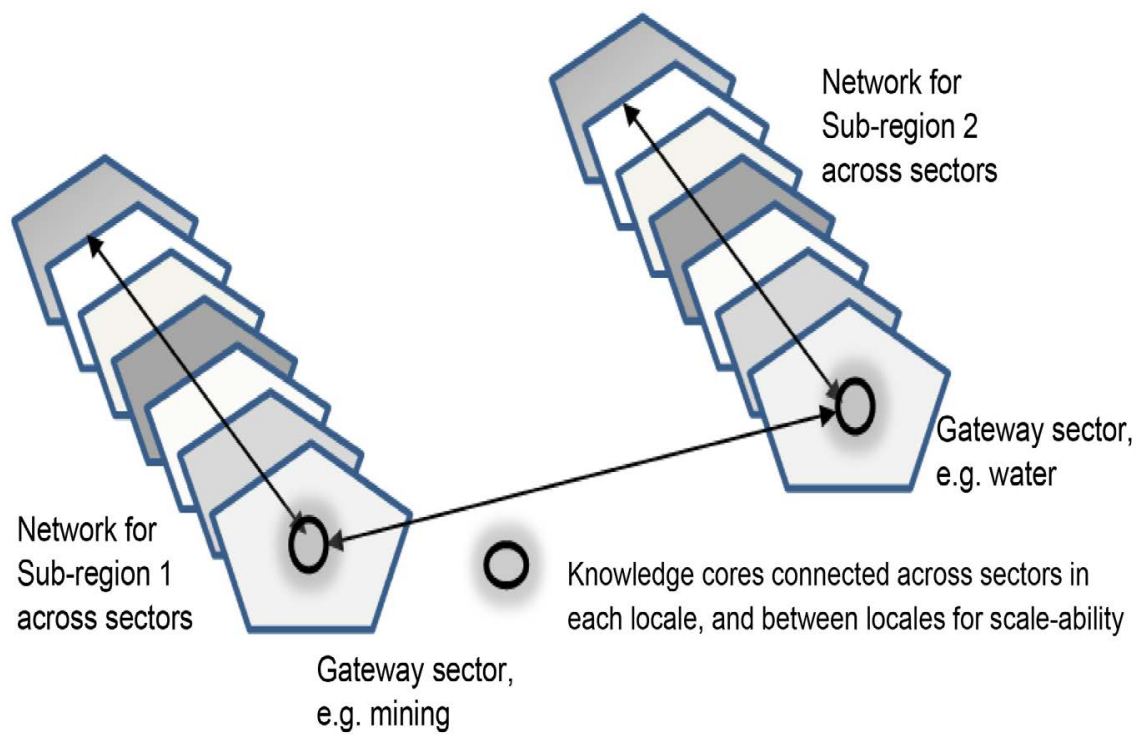

Figure 2. Capacity-building enterprise as a distributed socio-technical network. There are six levels of capacity for each sector, with information resources at the core of each (forming pentagons). Sectors integrate capacities at each level (e.g. Level 2: education and training across energy, water, food etc.), and connect via Level 3: the information resource core. Local and sub-region scale networks can be linked and scaled-up to regional and national scales (from Downs, 2018, by permission of SCIRP). 


\section{Conclusion}

Conga is not just another example of top-down BAU development; it is one that inspired popular resistance that successfully challenged this model. In its wake, the Minas Conga experience offers an excellent example of the three development conundrums, and illustrates the advantages of using a collaborative, integrative approach to understand and address them. Significantly, considerable social and political capital in Peru now opposes BAU practice and seeks alternatives: Conga experience can enable an integrative approach. Mining is a logical "gateway sector" for sustainable development because it is so impactful, with major inequities in the distribution of positive and negative impacts, and it connects with so many others-energy, water, food, industry, health, climate change. In light of this experience, we recommend that development problems and challenges be reframed as opportunities for the creation of place-based socio-technical capacity building enterprises locally, but then interconnect and scale-up via knowledge networks. On a positive note, sustainability principles are finding their way into the messaging of major companies; this may signal an opening for major reform, with companies seeking authentic partnerships with empowered civil society and others for a sustainable future.

\section{Conflicts of Interest}

The authors declare no conflicts of interest regarding the publication of this paper.

\section{References}

Armstrong, R., Baillie, C., Fourie, A., \& Rondon, G. (2014). Mining and Community Engagement in Peru. Communities Telling Their Stories to Inform Future Practice. Unpublished Report.

http://im4dc.org/wp-content/uploads/2013/09/Armstrong-Baillie-Peru-FR-Completed -Report.pdf

Bamberger, M. (1988). The Role of Community Participation in Development Planning and Project Management. Report of a Workshop on Community Participation (pp. 1-50). The International Bank for Reconstruction and Development, The World Bank.

BankTrack (2012). Minas Conga Peru. http://www.banktrack.org/show/dodgydeals/minas conga mining project\#tab dodgy deals basics

Bebbington, A., \& Williams, M. (2008). Water and Mining Conflicts in Peru. Mountain Research and Development, 28, 190-195. https://doi.org/10.1659/mrd.1039

Bebbington, A., Bury, J., Humphreys-Bebbington, D., \& Lingan, J. (2008). Mining and Social Movements: Struggles over Livelihood and Rural Territorial Development in the Andes. World Development, 36, 2888-2905.

https://doi.org/10.1016/j.worlddev.2007.11.016

Bury, J. (2004). Livelihoods in Transition: Transnational Gold Mining Operations and Local Change in Cajamarca, Peru. The Geographical Journal, 170, 78-91.

http://www.jstor.org/stable/3451330

https://doi.org/10.1111/j.0016-7398.2004.05042.x 
Bury, J. (2005). Mining Mountains: Neoliberalism, Land Tenure, Livelihoods, and the New Peruvian Mining Industry in Cajamarca. Environment and Planning, 37, 221-237. https://doi.org/10.1068/a371

CAO (Office of the Compliance Advisor Ombudsman for International Finance Corporation) (2014). CAO Assessment Report Regarding Local Concerns in Relation to IFC's Yanacocha Project (\#2983) in Cajamarca, Peru (pp. 1-9).

http://www.cao-ombudsman.org/cases/document-links/documents/Yanacocha7CAOA ssessmentReportEnglishJuly.pdf

Chambers, R. (1995). Rural Development: Putting the Last First. Harlow, UK: Addison-Wesley Publishing Co.

Chambers, R. (1997). Whose Reality Counts?: Putting the First Last. London: Intermediate Technology. https://doi.org/10.3362/9781780440453

Chambers, R. (2008). Revolutions in Development Inquiry. London: Earthscan.

CIA (2016). World Factbook. South America: Peru. https://www.cia.gov/library/publications/the-world-factbook/geos/pe.html

CIEL (2015). Environmental Risks and Human Rights Violations in Peru Mining in Celendin. Center for International Environmental Law.

http://www.ciel.org/environmental-risks-and-human-rights-violations-in-peru-mining -in-celendin/

Downs, T. J. (2001). Making Sustainable Development Operational: Integrated Capacity Building for the Water Supply and Sanitation Sector in Mexico. Journal of Environmental Planning and Management, 44, 525-544.

https://doi.org/10.1080/09640560120060948

Downs, T. J. (2007). A Systematic Integrated Approach for Crafting Poverty Reduction and Sustainable Development Projects. Natural Resources Forum-United Nations Sustainable Development Journal, 31, 35-50.

https://doi.org/10.1111/j.1477-8947.2007.00129.x

Downs, T. J. (2008). Transforming Impact Assessment for Sustainable Development and Poverty Eradication. Journal of Engineering Sustainability, 116, 39-54. https://doi.org/10.1680/ensu.2008.161.1.39

Downs, T. J. (2018). An Integrative Socio-Technical Enterprise Approach to Urban Design/Planning for Sustainable Development. Open Journal of Civil Engineering, 8, 183-204. https://doi.org/10.4236/ojce.2018.82015

Downs, T. J., \& Mazari-Hiriart, M. (2017). Addressing Risk Conundrums in Megacity Development: Mexico City. In R. Kasperson (Ed.), Risk Conundrums: Solving Unsolvable Problems (276 p.). New York: Earthscan/Routledge. https://doi.org/10.4324/9781315665894-11

Downs, T. J., Carr, E., \& Goble, R. (2017). Addressing Risk Conundrums in Sustainable Development. In R. Kasperson (Ed.), Risk Conundrums: Solving Unsolvable Problems (276 p.). New York: Earthscan/Routledge. https://doi.org/10.4324/9781315665894-16

GEF (2016). The Global Environment Facility. https://www.thegef.org/gef/

Gifford, B., \& Kestler, A. (2008). Toward a Theory of Local Legitimacy by MNEs in Developing Nations: Newmont Mining and Health Sustainable Development in Peru. Journal of International Management, 14, 340-352.

https://doi.org/10.1016/j.intman.2007.09.005

Hallman, B. (2015). How One Woman Is Standing Up to a Gold Mining Goliath. The Huffington Post.

Hallman, B., \& Olivera, R. (2015). Gold Rush: How the World Bank Is Financing Envi- 
ronmental Destruction. The Huffington Post.

Hilson, G., \& Murck, B. (2000). Sustainable Development in the Mining Industry: Clarifying the Corporate Perspective. Resources Policy, 26, 227-238.

https://doi.org/10.1016/S0301-4207(00)00041-6

INDC/Peru (2015). Intended Nationally Determined Contribution. Republic of Peru. https://www4.unfccc.int/sites/NDCStaging/pages/Party.aspx?party=PER

Jamasmie, C. (2016). Community Opposition Forces Newmont to Abandon Conga project in Peru.

http://www.mining.com/community-opposition-forces-newmont-abandon-conga-proj ect-peru/

Javier A, Y. (2008). A Thoroughly Modern Resource Curse? The New Natural Resource Policy Agenda and the Mining Revival in Peru (pp. 1-51). Center for the Future State, Institute of Development Studies.

LEAP (2015). The Leap Manifesto. https://leapmanifesto.org/en/the-leap-manifesto/

Meadow, A., Ferguson, D., Guido, Z., Horangic, A., \& Owen, G. (2015). Moving toward the Deliberate Coproduction of Climate Science Knowledge. American Meteorological Society. https://doi.org/10.1175/WCAS-D-14-00050.1

Moran, R. (2012). The Conga Mine, Peru: Comments on the Environmental Impact Assessment (EIA) and Related Issues (pp. 1-28.). Report Prepared for Environmental Defender Law Center.

Newmont (2017). 2017 Sustainability Report: Beyond the Mine.

https://s3-us-west-2.amazonaws.com/ungc-production/attachments/cop 2018/462859/ original/Newmont-Beyond-The-Mine-Sustainability-Report-2017.pdf?1524494306

PIIC (Plataforma Inter-Institucional Celendina) (2013). Call to Action in Support of the Rondas Campesinas.

https://congaconflict.wordpress.com/2013/11/29/call-to-action-in-support-of-the-rond as-campesinas/

Slocum, N. (2003). Participatory Methods Toolkit: A Practitioner's Manual (pp. 1-167.). King Baudouin Foundation and the Flemish Institute of Science and Technology Assessment.

Smith, D. N. (1988). Flora and Vegetation of the Huascarán National Park, Ancash, Perú, with Preliminary Taxonomic Studies for a Manual of the Flora. PhD. Dissertation, Ames, IA: Iowa State University.

Triscritti, F. (2013). Mining, Development and Corporate-Community Conflicts in Peru. Community Development Journal, 48, 437-450. https://doi.org/10.1093/cdj/bst024

UN (2014). In Peru, Where Evidence of Climate Change Is Abundant, Hope for a Solution Is, too. United Nations.

http://www.un.org/climatechange/blog/2014/11/peru-evidence-climate-change-abunda nt-hope-solution/

UN/DESA (2016). Back to Our Common Future. Sustainable Development in the 21st Century (SD21) Project.

https://sustainabledevelopment.un.org/content/documents/UN-DESA Back Common Future En.pdf

UNDRIP (2008). United Nations Declaration on the Rights of Indigenous Peoples. http://www.un.org/esa/socdev/unpfii/documents/DRIPS en.pdf

Vela-Almeida, D., Kuijk, F., Wyseure, G., \& Kosoy, N. (2016). Lessons from Yanacocha: Assessing Mining Impacts on Hydrological Systems and Water Distribution in Cajamarca Region, Peru. Water International, 41, 426-446. 
https://doi.org/10.1080/02508060.2016.1159077

Vuille, M., \& Francou, B. (2008). Climate Change and Tropical Andean Glaciers: Past, Present and Future. Earth Science Reviews, 89, 79-96. https://doi.org/10.1016/j.earscirev.2008.04.002

WWF (2010). Study of the Environmental Impact Assessment for the Conga Mining Project in Cajamarca, Peru. World Wildlife Fund, Netherlands.

https://justiceprojectdotorg1.files.wordpress.com/2017/08/wwf-conga cajamarca stud y 2012.pdf 


\section{Appendix}

Summary of EIA Conclusions for Water Impacts (WWF, 2012). Integrative critique added (see also Vela-Almeida et al., 2016).

\section{Water Aspect Named}

EIA Findings

(WWF, 2012)
Integrative Critique

(see also Vela-Almeida et al., 2016)
1) “...four lakes to be removed"

2) "Uses of surface water"

3) "Drinking water sources"

4) "High coliform levels"

5) “Groundwater quality”
Mitigation: "Water storage reservoirs designed to assure a year-round supply of water to downstream users will replace the four lakes to be removed by the Conga Project. The water storage reservoirs will allow for water to be released throughout the year, particularly during the dry season."

"Agricultural uses for crop irrigation and livestock are the predominant uses of surface water emanating from the project area".

"Natural springs serve as the principal source of drinking water for the communities in the immediate vicinity of the Conga Project".

"Coliform levels often exceed standards due to the presence of livestock and limited sewage management in the area".

"Pre-project groundwater quality reflects the natural mineralization within the project area and exceeds some standards for metals".
Such very large-scale open-pit extractive operations for gold and copper completely change land use and land cover, with high soil erosion. The use of toxics like cyanide and mercury, and large volumes of tailings and mining waste have high potential to contaminate soils, surface waters and groundwaters through runoff and infiltration. The loss of four natural lakes has major impacts on surface-water and groundwater hydrology. How the storage reservoirs compensate for impacts to flow patterns as well as magnitudes needs to be carefully modeled. Conga amplifies the adverse impacts from Yanacocha: What have these been? How are they projected to change with Conga?

Given the risks of surface water and groundwater contamination, (runoff and infiltration), soil erosion, and downstream sedimentation, it is likely that crop irrigation and livestock will be impacted by contaminated flows. These adverse flows cannot be eliminated by the replacement of natural flow volumes by storage reservoirs. Again, data on impacts from Yanacocha's many years of operation need to be used as input data to hydrological modeling of impacts.

Springs are outcroppings of high water table groundwaters, and can be seasonal. Aspect \#5 is worrisome, esp. the exceedance of standards for metals. Which metals? Mercury is a super-toxic agent, as is cyanide (secondary decay product of hydrocyanic acid). Yanacocha has history of $\mathrm{Hg}$ spillage and health impacts. Groundwaters are recharged by the infiltration of precipitation, so aquifers within and down-gradient of the large mining site can be impacted, especially as it would seem (from springs) that they are surficial or near-surface.

Any changes to water supply sources - e.g. storage reservoirs - should be accompanied by corresponding investments in wastewater sanitation.

To be clear, the 10-13 years of "baseline" monitoring data used for the EIA are capturing the impacts of Yanacocha Mine. It is important to distinguish which chemicals (metals, inorganics and organics) are natural and which are from mining in order to estimate the projected impacts on groundwaters from Conga. 


\section{Continued}

6) "Wetland degradation"

7) "Lack of groundwater aquifers"

8) "Groundwater contribution to stream flow"

9) "Natural lake contribution to surface water flows"

10) "EIA recommendations to base flow"
"Wetlands within the project area are severely degraded in many areas due to past overgrazing by livestock, and in some cases due to naturally occurring poor quality water (e.g., low pH and elevated iron). Baseline studies rated many of the wetlands as "poor" to "very poor" in terms of habitat biodiversity and ecosystem quality".

"No useable groundwater aquifers exist within the strata to be mined".

"Groundwater accounts for approximately $3 \%$ of base flow in receiving streams. This groundwater contribution represents the low flow conditions in the streams during the dry season".

"Natural lakes contribute minimally to surface water flows in the vicinity of the project area, especially during the dry season. The water balance calculations assume a conservative 3\% loss to groundwater, which during the dry season would report as surface water. As an example, for Perol Lake this would be equivalent to less than $3 \%$ of the current dry season flow rate".

"Base flow replacements committed to in the EIA will equal or exceed current flow conditions during the dry season".
It is unclear how much of the degradation of wetlands is from livestock vs. Yanacocha mining. This highlights the importance of using an appropriate pre-mining baseline for wetlands/biodiversity in comparable socio-ecological systems without mining. Low $\mathrm{pH}$ could be natural if soils are acidic, but could also be attributable to acidic tailings/runoff from Yanacocha mining site. By using GIS to model hydrology and map wetlands and farming activities, this can be interrogated. On a more subtle note, the language chosen by the EIA has the appearance of being biased in favor of mining interests, and reluctant to link existing or projected mining to adverse impacts.

Once again this seems biased and misleading from a systems view. Aquifers do not have to be located in mined strata to be impacted by mining up-gradient. Robust hydrogeological modeling would reveal flow fields and impact areas within hydrological basins and sub-basins.

It is not unusual for groundwater to contribute a few $\%$ to wet season flows, especially in humid tropics - then $100 \%$ during dry season.

This may be so: in the comparison between contributions to stream flows from runoff vs. lake outflow, it's not unusual in the tropics for runoff to dominate strongly. However, lakes are important storage reservoirs in hydrological basins, and they help to stabilize stream flows and trap suspended sediments. The more pressing question this finding may obscure is that runoff from mining lands will have major impacts on the quantity and quality of down-gradient stream flows and lake quality.

See above. This mitigation may obscure the more significant impacts from very large-scale contaminated runoff. 